Bài báo khoa hoc

\title{
Nghiên cứu phân vùng chất lượng nước mặt theo diễn biến phát triển các vùng kinh tế của tỉnh Bạc Liêu
}

\author{
Huỳnh Phú ${ }^{*}$ \\ ${ }^{1}$ Trường Đại học Công nghệ TP Hồ Chí Minh (HUTECH); h.phu@hutech.edu.vn \\ * Tác giả liên hệ: h.phu@hutech.edu.vn; Tel.: +84-966687548
}

Ban Biên tập nhận bài: 05/03/2021; Ngày phản biện xong: 11/4/2021; Ngày đăng bài: 25/5/2021

Tóm tắt: Bài báo trình bày nghiên cứu phân vùng chất lượng nước mặt theo diễn biến phát triển các vùng kinh tế của tỉnh Bạc Liêu. Phát triển kinh tế hiệu quả mà nguồn nước là tư liệu sản xuất thiết yếu, chất lượng nước quyết định sự thành công hay thất bại, cần phân tích tổng hợp các yếu tố đặc trưng về nguồn nước tại các vùng là sự tổ hợp những yếu tố có tính phân bố không gian, chế độ ngập, chất lượng nước cho quy hoạch nông lâm ngư nghiệp, du lịch...Nghiên cứu sử dụng các phương pháp, điều tra khảo sát, lấy mẫu, phân tích các chỉ tiêu hóa lý (TSS, BOD 5 , COD, N-NH $, \mathrm{N}-\mathrm{NO}_{2}, \mathrm{P}-\mathrm{PO}_{4}$, Coliform...), tính toán chỉ số WQI; So sánh với QCVN 08-MT: 2015/BTNMT. Kết quả đã phân vùng chất lượng nước: (i) Vùng phát triển kinh tế hiệu quả vùng sinh thái phía Bắc Quốc Lộ $1 \mathrm{~A}$, có diện tích tự nhiên 157.224 ha và được chia thành 02 Tiểu vùng; (a) Tiểu vùng giữ ngọt ổn định (sinh thái ngọt), có diện tích tự nhiên 75.720 ha; (b) Tiểu vùng chuyển đổi sản xuất sinh thái mặn lợ đan xen, trong đó 35.609 ha, đất tôm-lúa 23.134 ha, đất sản xuất nông nghiệp 12.274 ha; (ii) Vùng phát triển các ngành vận tải và du lịch biển, mở rộng hợp tác quốc tế và bảo vệ an ninh, quốc phòng.

Từ khóa: Bạc liêu; Nước mặt; Phân vùng kinh tế; Sinh thái mặn lợ; Tiểu vùng sinh thái.

\section{Mở đầu}

Bạc Liêu có hai nguồn nước mặt chính, nguồn nước mặn, lợ và nguồn nước ngọt, mỗi loại có những đặc điểm riêng về nguồn cung cấp và tiềm năng khai thác sử dựng. Tài nguyên nước mặn, lợ phần lớn địa bàn tỉnh Bạc Liêu chịu ảnh hưởng trực tiếp của triều biển Đông và biển Tây, có hệ thống kênh rạch chằng chịt, ăn thông với nhau nên nguồn nước mặn rất dồi dào, có khuynh hướng lấn át nguồn nước ngọt, tuy nhiên do biển Đông và biển Tây vừa là nguồn cấp nước mặn, vừa là nơi nhận nước tiêu thoát cho khu vực ĐBSCL [1-4]. Nguồn nước mặn trên địa bàn tỉnh Bạc Liêu hiện đang được khai thác sử dụng chủ yếu cho nuôi trồng thủy sản nước mặn/lợ, làm muối và bảo vệ các khu rừng ngập mặn [5-6]. Tài nguyên nước ngọt, nguồn nước chủ yếu là nước mưa tại chỗ, một phần được bổ sung từ nguồn nước sông Hậu. Hiện nay, lượng nước mưa đủ đáp ứng yêu cầu sản xuất của tỉnh trong mùa mưa. Riêng mùa khô, nguồn nước bổ sung từ sông Hậu cho sản xuất vẫn còn hạn chế, do tỉnh nằm ở cuối nguồn và chỉ có một trục cung cấp nước ngọt duy nhất là kênh Quản Lộ-Phụng Hiệp. Nguồn nước ngọt phục vụ sản xuất nông nghiệp, nuôi trồng thủy sản trong mùa khô gặp rất nhiều khó khăn, đặc biệt là trong các năm hạn hán, mặn xâm nhập sâu. Dưới tác động của sự gia tăng dân số và tăng trưởng kinh tế, nguồn nước nói chung, đặc biệt là nguồn nước mặt đang ngày càng bị lạm dụng. Quá trình đô thị hóa, hoạt động nông nghiệp, công nghiệp gây áp lực nặng nề lên khối lượng và chất lượng nguồn nước [7]. Hiện nay, có rất nhiều phương 
pháp đánh giá chất lượng nước (CLN) trên thế giới tùy thuộc vào tình hình cụ thể mỗi Quốc gia trên thế giới. Một số phương pháp đánh giá CLN mặt đã áp dụng trên thế giới thông qua một số nghiên cứu đã được thực hiện. Năm 1983, nghiên cứu [8] sử dụng các chỉ số chất lượng nước để phân loại và phân vùng sông Ganga. Năm 1987, [1] đã thực hiện nghiên cứu áp dụng chỉ số chất lượng nước cho việc phân loại và phân vùng kênh $\mathrm{Al}$ - jaysh, Baghdad-Iraq. Năm 1990, nghiên cứu chất lượng nước mặt lưu vực thượng lưu sông Illinois ở Illinois, Indiana và Wisconsin, Hoa kỳ Bộ Nội Vụ Hoa Kỳ và Sở Khảo Sát Địa Lý Hoa Kỳ [2]. Năm 2004, [9] nghiên cứu quy hoạch chất lượng nước sông, một nghiên cứu về hệ thống sông Karoon và Dez. Năm 2011, công trình nghiên cứu [6] chất lượng nước mặt sông Tùng Hoa, Cáp Nhĩ Tân, tỉnh Hắc Long Giang, Trung Quốc. Năm 2015, [10] nghiên cứu phân vùng bảo tồn nước nông thôn tại lưu vực sông Ashihe, Trung Quốc. Dựa trên toàn diện khu vực sản xuất hóa chất ở Trung Quốc, chia thành 3 vùng Đông Monsoon Trung Quốc.

Nghiên cứu phân vùng chất lượng nước theo WQI và đánh giá khả năng sử dụng các nguồn nước sông, kênh rạch ở vùng Tp.HCM [11]. Nghiên cứu đã nêu rõ diễn biến chất lượng nước các sông rạch chính theo không gian và thời gian; thiết lập hệ thống WQI phù hợp cho TP. HCM (và cả lưu vực sông Đồng Nai-Sài Gòn) và tính WQI cho 35 điểm khảo sát vào tháng 3 và tháng 9/2007. Dựa vào điểm số về WQI chất lượng nước tại các điểm đã được phân thành 5 loại $(\mathrm{I}-\mathrm{V})$ [11-14]. Nghiên cứu còn phân vùng CLN theo từng thông số điển hình (ô nhiễm hữu cơ, axit hóa, nhiễm mặn, ô nhiễm dinh dưỡng, vi sinh và phân vùng CLN theo WQI) kết quả phân vùng đã được thể hiện trên các bản đồ số hóa. Nghiên cứu chỉ tập trung vào việc xây dựng chỉ số chất lượng nước làm công cụ cho việc đánh giá chất lượng nước nên không chú trọng vào việc đề xuất các biện pháp bảo vệ lưu vực sông. Nghiên cứu của Đại học Huế về ứng dụng chỉ số chất lượng nước (WQI) và hệ thống thông tin địa lý để phân vùng chất lượng nước nuôi tôm ở đầm phá xã Phú Thuận, huyện Phú Vang, tỉnh Thừa Thiên Huế [15-16]. Trung tâm Quan trắc và Công nghệ Tài nguyên-Môi trường, An Giang đánh giá chất lượng nước mặt bởi chỉ số chất lượng nước (WQI) tại rạch Cái Sao, tỉnh An Giang, Việt Nam [17], đánh giá chất lượng nước mặt của các chỉ số chất lượng nước (WQI) tại rạch Cái Sao, tỉnh An Giang đã được tiển hành để cung cấp một cơ sở dữ liệu cho việc lập kế hoạch và giám sát chất lượng nước ở khu vực này [18]. Kết quả chỉ số chất lượng nước (WQI) phạm vi 39-29 cho thấy ô nhiễm nhẹ tại hai địa điểm gần với sự gia nhập của các kênh với dòng sông, tăng ô nhiễm nghiêm trọng cùng với phần còn lại của kênh.

Ở Việt Nam, phương pháp đánh giá WQI đã được các nhà khoa học nghiên cứu và áp dụng cho một vài lưu vực sông. Trong những năm gần đây phương pháp này được nghiên cứu và cải tiến để áp dụng cho hệ thống lưu vực sông, cụ thể: Nghiên cứu phân vùng chất lượng nước sông Hương theo chỉ số chất lượng nước (WQI) góp phần bảo vệ và khai thác nguồn nước [19]. Nghiên cứu đã nêu rõ thông qua đánh giá CLN sông Hương dựa vào các thông số CLN riêng biệt ở 3 tiểu vùng từ 2003 đến 2008 đã cho thấy những lo lắng về CLN sông Hương bao gồm: sự ô nhiễm vi khuẩn, sự ô nhiễm hữu cơ đánh giá qua COD, amoni, các kêt quả đánh giá CLN tổng quát (hay CLN cho đa mục đích sử dụng) theo chỉ số CLN (WQI) cho thấy CLN sông Hương giảm dần từ đầu nguồn về cuối nguồn và biến động phức tạp theo không gian, thời gian, trên cơ sở đánh giá CLN qua WQI, đã phân vùng CLN sông Hương cho các mục đích sử dụng theo từng vùng. Tuy nhiên, nghiên cứu chỉ tập trung vào việc đánh giá và phân vùng chất lượng nước nên không chú trọng vào việc đề xuất giải pháp quản lý chất lượng nước trên địa bàn nghiên cứu [19].

Tại tỉnh Bạc Liêu "Báo cáo hiện trạng môi trường tỉnh Bạc Liêu giai đoạn 2015-2020" [14]. Hiện trạng môi trường 5 năm được thực hiện nhằm tổng kết các số liệu về quan trắc chất lượng môi trường từ đó đánh giá diễn biến môi trường, sự tác động qua lại của phát triển kinh tế-xã hội và môi trường cũng như tình hình hoạt động bảo vệ môi trường của địa phương. Báo cáo đưa ra những thay đồi của môi trường để trên cơ sở đó đề xuất các chính sách và biện pháp đáp ứng nhằm giải quyết các vấn đề môi trường. Mặc dầu các vấn đề liên quan đến phát triển tài nguyên nước trên địa bàn tỉnh Bạc Liêu đã được nhiều cơ quan trong và ngoài nước 
nghiên cứu, nhưng các nghiên cứu mang tính đơn ngành và chủ yếu tập trung vào khai thác nguồn nước mà chưa đi sâu vào quản lý tài nguyên nước trên cơ sở bảo vệ môi trường sinh thái đảm bảo phát triển bền vững.

\section{Phương pháp nghiên cứu}

\subsection{Khu vục nghiên cứu}

Tỉnh Bạc Liêu là một trong những tỉnh ven biển Đồng bằng sông Cửu Long, nằm ở phía Đông bán đảo Cà Mau. Tỉnh có diện tích tự nhiên là $266.900,08$ ha và có tọa độ từ 900 '0" đến 9038'9" vĩ độ Bắc và từ 105014'15" đến 105051'54" kinh độ Đông. Phía Bắc và Tây Bắc giáp tỉnh Hậu Giang và Kiên Giang. Phía Đông và Đông Bắc giáp tỉnh Sóc Trăng. Phía Tây và Tây Nam giáp tỉnh Cà Mau. Phía Đông và Đông Nam giáp biển Đông. Các đơn vị hành chính trên địa bàn tỉnh bao gồm thành phố Bạc Liêu, thị xã Giá Rai và 05 huyện: Hồng Dân, Phước Long, Vĩnh Lợi, Đông Hải và Hòa Bình với tổng cộng 64 xã, phường, thị trấn [20] (Hình 1).

BẢN ĐỒ HÀNH CHÍNH TỈNH BẠC LIÊU

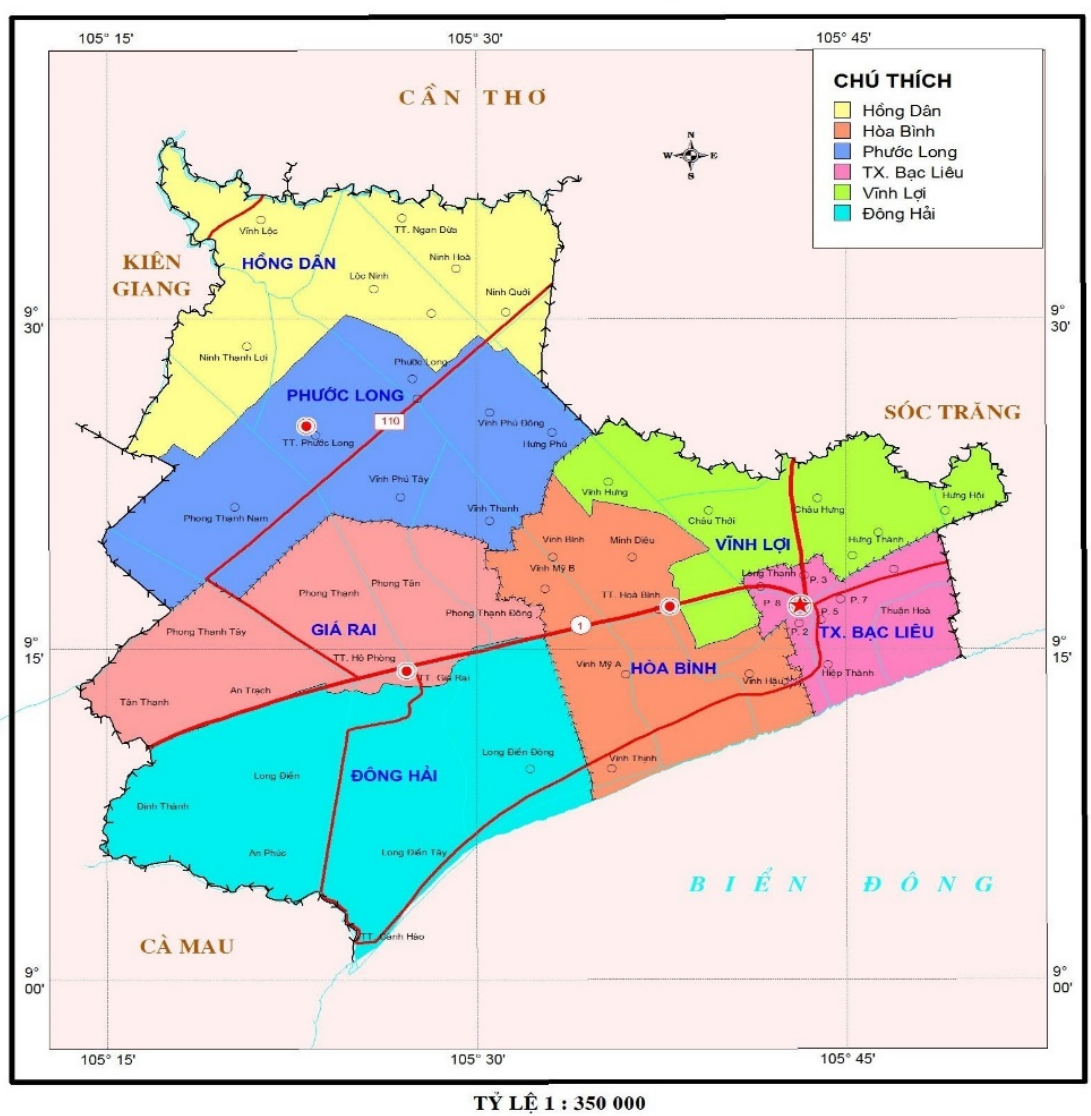

Hình 1. Bản đồ hành chính tỉnh Bạc Liêu.

\subsection{Hiện trạng diễn biến môi truờng nuớc mặt tỉnh Bạc Liêu}

Tài nguyên nước ngọt: Nguồn nước chủ yếu là nước mưa tại chỗ, một phần được bổ sung từ nguồn nước sông Hậu. Hiện nay, lượng nước mưa đủ đáp ứng yêu cầu sản xuất của tỉnh trong mùa mưa. Riêng mùa khô, nguồn nước bổ sung từ sông Hậu cho sản xuất vẫn còn hạn chế, do tỉnh nằm ở cuối nguồn và chỉ có một trục cung cấp nước ngọt duy nhất là kênh Quản Lộ-Phụng Hiệp. Nguồn nước ngọt phục vụ sản xuất nông nghiệp và nuôi trồng thủy sản trong mùa khô còn gặp rất nhiều khó khăn, đặc biệt là trong các năm hạn hán, mặn xâm nhập sâu. 
Tài nguyên mặn: Phần lớn địa bàn tỉnh Bạc Liêu chịu ảnh hưởng trực tiếp của triều biển Đông và biển Tây, Vùng Bắc QL1A, sau năm 2001 đã điều chỉnh cho phép điều tiết nước mặn từ biển Đông vào để phục vụ nuôi trồng thủy sản, phần còn lại được bảo vệ, chống xâm nhập mặn để sản xuất nông nghiệp. Đây là một yêu cầu rất khắt khe và hết sức khó khăn nhằm đảm bảo điều tiết nước hợp lý cho các tiểu vùng, nguồn nước mặn trên địa bàn tỉnh Bạc Liêu hiện đang được khai thác sử dụng chủ yếu cho nuôi trồng thủy sản nước mặn/lợ, làm muối và bảo vệ các khu rừng ngập mặn [4-5].

\subsection{Phưong pháp thu thập, phân tích và tổng hợp tài liệu}

+ Thu thập các tài liệu về điều kiện tự nhiên, KTXH, môi trường đặc biệt là các tài liệu về điều kiện thủy văn sông, rạch chính trên địa bàn tỉnh Bạc Liêu;

+ Thu thập, thống kê và cập nhật các đặc trưng nguồn nước thải, đặc điểm nguồn tiếp nhận từ quá trình điều tra, từ các dự án, nghiên cứu nghiên cứu liên quan, từ các cơ quan nghiên cứu, các sở, ngành, huyện thị, các cơ sở sản xuất, kinh doanh, dịch vụ đang hoạt động của tỉnh Bạc Liêu;

+ Tổng hợp, thống kê, xử lý các số liệu, dữ liệu về khí tượng, thủy văn, kinh tế xã hội dựa trên phương pháp thống kê và phân tích [20];

+ Thống kê, xử lý, phân tích số liệu về các nguồn thải khác nhau xả vào các lưu vực sông điều tra để tính toán WQI nhằm đánh giá khả năng tiếp nhận nước thải csủa nguồn nước.

\subsection{Phuoong pháp khảo sát thực địa, đo đạc thủy văn, lấy mẫu phân tích}

Phương pháp này được thực hiện nhằm khảo sát thực địa, đo đạc thủy văn, lấy mẫu phân tích nước thải, mẫu nước sông phục vụ tính toán WQI đánh giá chất lượng nước so sánh với QCVN 08-MT 2015/BTNMT [21].

\subsection{Phân vùng chất lượng nước}

\subsubsection{Nguyên tắc phân vùng}

Việc phân vùng tuân theo sự đồng nhất tương đối, tính đại diện cao, tổng hợp từ nhiều yếu tố KTTV, thổ nhưỡng, phát triển kinh tế... Nhân tố trội, mang tính quyết định, toàn vẹn lãnh thổ, khép kín, không lặp lại trong không gian. Phù hợp với cơ cấu sản xuất nông nghiệp hiện nay của tỉnh. Ranh giới các vùng, tiểu vùng chủ yếu là các sông, kênh lớn hoặc các tuyến ngăn cách tạo sự khác biệt giữa các vùng. Ngoài ra, khi xét ranh giới các vùng cũng chú ý đến ranh giới hành chính để tạo điều kiện thuận lợi trong việc quản lý đầu tư nâng cấp hệ thống trong tương lai.

\subsubsection{Cơ sở phân vùng}

Cơ sở đề xuất phân vùng sinh thái hệ sinh thái môi trường nước nhằm phục vụ phát triển kinh tế cho từng vùng cần dựa vào sự phân tích tổng hợp các yếu tố đặc trưng về nguồn nước nên các vùng được đề xuất sẽ là sự tồ hợp những yếu tố có tính phân bố không gian sau đây:

- Chế độ ngập (độ sâu ngập, thời gian ngập);

- Chất lượng nước (lợ, mặn, ngọt, (WQI), các chỉ tiêu hóa lý);

- Quy hoạch từng vùng kinh tế (nông lâm, ngư nghiệp thủy sản).

\subsubsection{Tiêu chí phân vùng}

Dựa trên sự tổ hợp các nhóm đặc trưng cho từng đối tượng sản xuất, chỉ có các yếu tố tạo ra sự phân nhóm rõ ràng của các đối tượng mới được chọn làm các yếu tố cơ sở để phân vùng, có đối chiếu các yêu cầu tối thiểu của từng vùng sản xuất kết hợp với tính kinh tế và tập quán sản xuất của người dân, khác với nhiều nơi, việc cấp nước ở Bạc Liêu không chỉ là cung cấp nước ngọt mà còn là nước mặn, nước lợ. 
Do chịu ảnh hưởng trực tiếp của triều Biển Đông và Biển Tây và có hệ thống kênh rạch chằng chịt, nguồn nước mặn ở tỉnh Bạc Liêu dồi dào và luôn có khuynh hướng lấn át nguồn nước ngọt. Hướng xâm nhập mặn từ biển Đông qua các kênh trục; trong đó tuyến sông Gành Hào-kênh xáng Gành Hào đóng vai trò quyết định. Ngoài ra, các kênh cấp I trực tiếp thông ra biển như: 30/4, Chùa Phật, Cái Cùng, Huyện Kệ; các kênh cấp II vượt cấp... Hướng xâm nhập mặn từ Cà Mau qua các cống Tắc Vân, Chắc Băng, Ông Hương, Thị Phụng và Đường Xuồng và kinh Chắc Băng; triều biển Tây theo sông Cái Lớn từ hướng Kiên Giang [5, 18, 20$]$. Vùng ngọt (Vùng được cung cấp nước ngọt thường xuyên và không bị nước mặn xâm nhập). Vùng nước lợ (vùng giáp nước, mặn-ngọt đan xen). Độ mặn $\mathrm{S}=2-4 \%$, thời gian nhiễm mặn $<6$ tháng. Vùng nước mặn (giáp biển và nước mặn xuất hiện quanh năm). Độ mặn $\mathrm{S}>4 \%$, thời gian nhiễm mặn $>6$ tháng.

\section{Kết quả nghiên cứu}

\subsection{Phát triển các vùng kinh tế tỉnh Bạc liêu}

\subsubsection{Phát triển nông nghiệp}

Giá trị sản xuất nông nghiệp theo giá hiện hành giai đoạn 2015-2019 tỉnh Bạc Liêu được thể hiện trên hình 2.

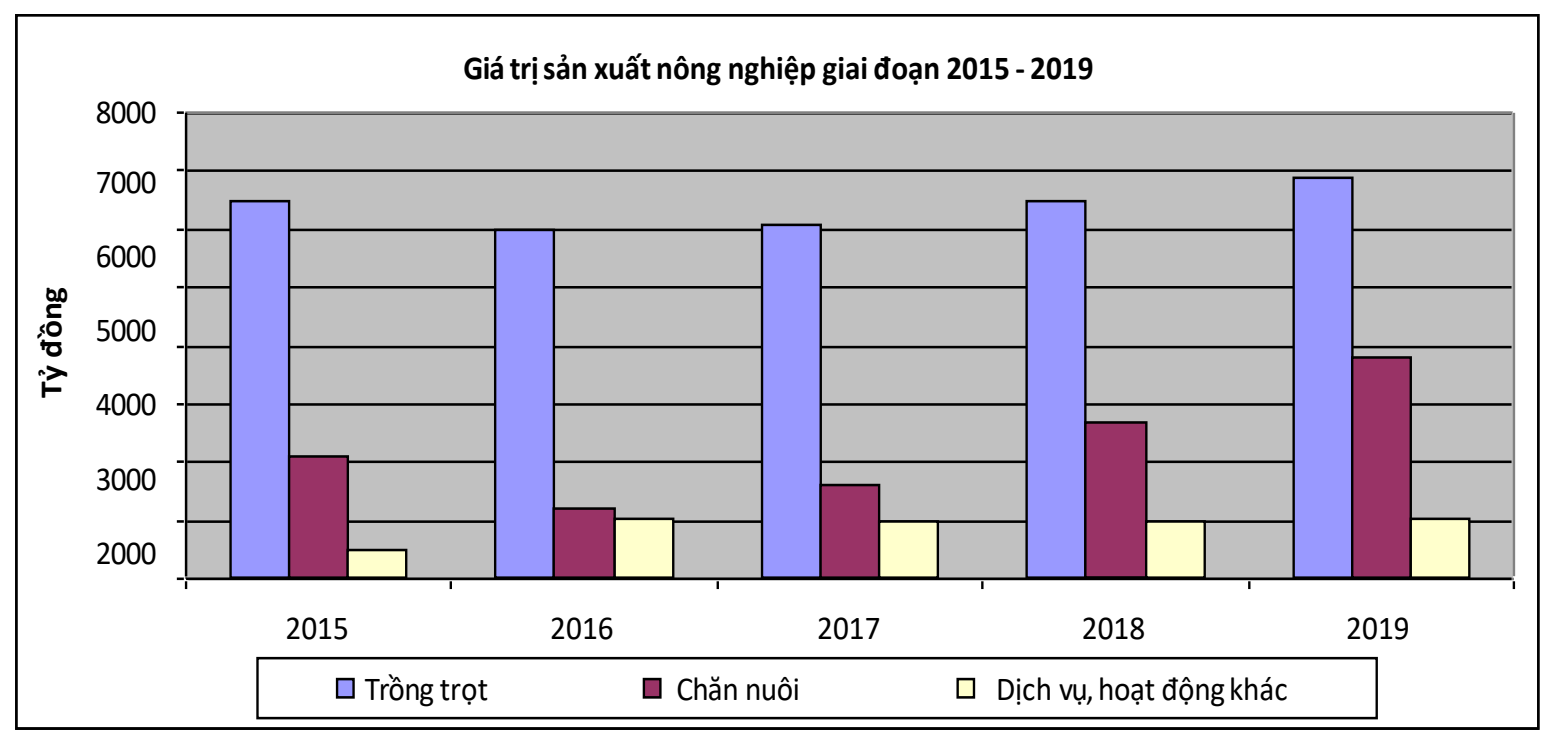

Hình 2. Giá trị sản xuất nông nghiệp giai đoạn 2015 -2019.

Trong cơ cấu sản xuất nông nghiệp, trồng trọt chiếm tỷ trọng cao ( $>70 \%$ cơ cấu ngành), hoạt động dịch vụ và các hoạt động khác có sự gia tăng tỷ trọng từ 5,6-10,95\% năm 2015-2016, tuy nhiên giảm xuống 10,6 năm 2017. Chăn nuôi có sự suy giảm từ $23,63 \%$ năm 2015 xuống còn $16,55 \%$ năm 2016 , nhưng đang có dấu hiệu phục hồi lên $17,55 \%$ trong năm 2018 và tăng lên 25,14 trong năm 2019.

Sản xuất lúa: Tính đến quý I năm 2020, toàn tỉnh đã xuống giống 46.632 ha lúa vụ đông xuân 2019-2020, ước tính thu hoạch 16.000ha, với sản lượng 105.000 tấn, đạt $11,2 \%$ kế hoạch, bằng $105 \%$ cùng kỳ, năng suất 7-7,5 tấn/ha, trong đó các giống lúa chất lượng cao chiếm 83,23\%; các giống lúa chất lượng thấp chiếm $12,03 \%$ diện tích gieo trồng lúa Đông Xuân. Các cây trồng khác, rau đậu thực phẩm cũng được người dân tích cực sản xuất, do giá cả đầu ra ổn định, cho hiệu quả kinh tế cao và bền vững trên cùng đợn vị diện tích canh tác. Trong quý, đã xuống giống 3.600 ha (màu trên rẫy 3.200 ha, màu xuống ruộng 400 ha), thu hoạch 2.000 ha. 


\subsubsection{Phát triển thủy sản}

Dựa theo số liệu từ niên giám thống kê cho thấy diện tích NTTS năm 2015 là 126.266 ha giảm xuống còn 123.741 ha năm 2016, tăng lên 127.883 ha năm 2017 và giảm xuống 127.502 ha trong năm 2018, trong đó diện tích nuôi thâm canh là 10.727 ha, bán thâm canh là 5.084 ha, quảng canh và quảng canh cải tiến là 111.745 ha.

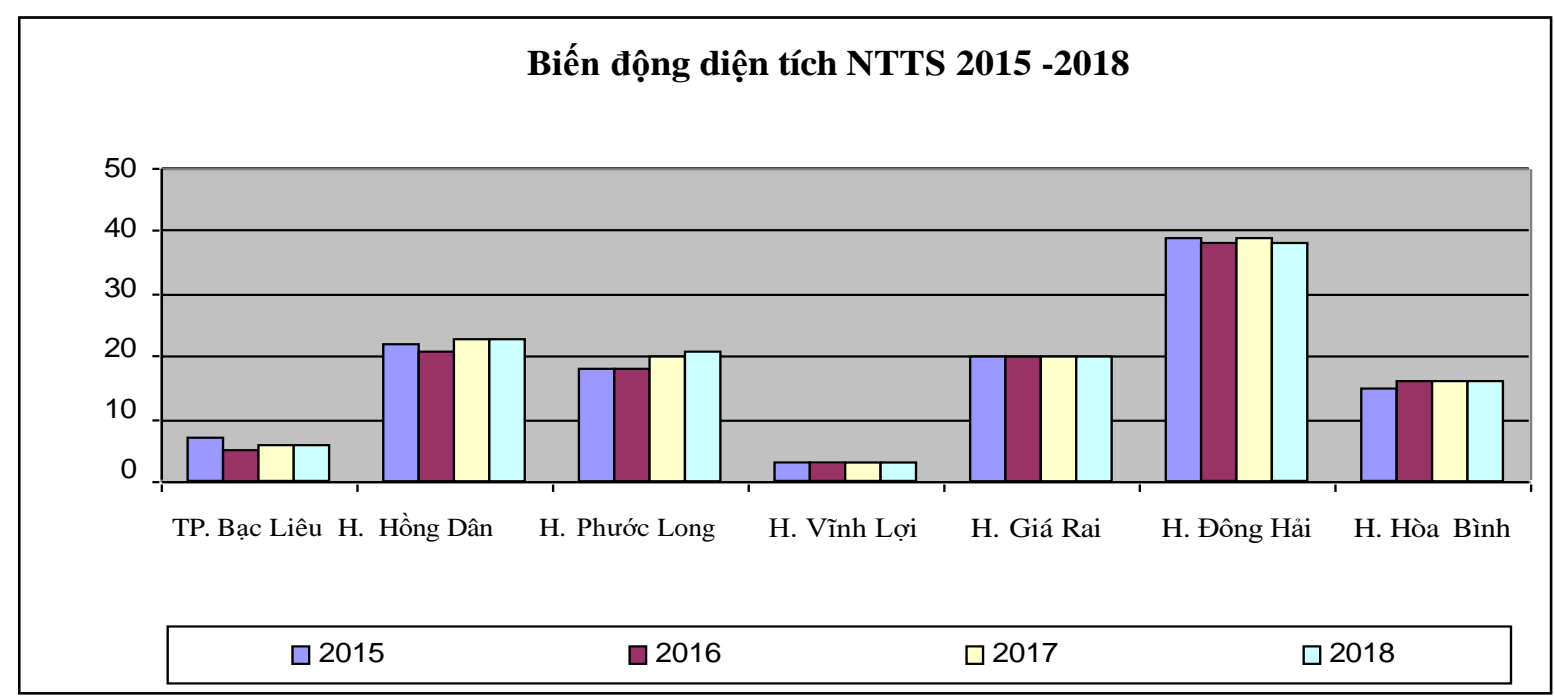

Hình 3. Biến động diện tích NTTS giai đoạn 2015-2018.

Mặc dù diện tích NTTS có suy giảm trong năm 2016 nhưng tổng sản lượng thủy sản nuôi trồng tăng dần qua các năm, từ 154.979 tấn năm 2015 lên 159.850 tấn năm 2016, 170.436 tấn năm 2017 và 178.106 tấn năm 2018.

\subsubsection{Phát triển du lịch}

Diễn biến các hoạt động và áp lực của ngành du lịch, số lượng khách du lịch đến tỉnh Bạc Liêu năm 2019 là 399.705 lượt khách, tăng hơn so năm 2018, trong đó có khoảng 17.320 du khách nước ngoài tăng hơn so với năm 2018. Tổng doanh thu dịch vụ du lịch khoảng 4.720 tỷ đồng và tăng $17,4 \%$ so với năm 2018. Dự báo trong giai đoạn 2020-2025, tỉnh Bạc Liêu thu hút 02 triệu lượt khác du lịch, trong đó khách quốc tế có từ 30.000-35.000 lượt; với hệ thống cơ sở lưu trú khoảng 4.000 buồng, $40 \%$ khách sạn đạt tiêu chuẩn từ 2 sao trở lên, trong đó có ít nhất $8 \%$ khách sạn đạt chuẩn 3-5 sao; thu thập từ du lịch đạt 3.000 tỷ đồng, chiếm tỷ trọng 3,89\% GDP tỉnh. Đến năm 2020-2030 đón hơn 4 triệu lượt khách du lịch, tăng gấp 2 lần so với giai đoạn 2020-2025; trong đó khách nước ngoài đạt gần 200.000 lượt; với hệ thống cơ sở lưu trú khoảng 20.000 buồng, $50 \%$ đạt tiêu chuẩn từ 2 sao trở lên, trong đó ít nhất $12 \%$ khách sạn đạt chuẩn từ 3 đến 5 sao; thu thập từ du lịch đạt 12.000 tỷ đồng tăng gấp 4 lần so với giai đoạn 2020-2025, chiếm tỷ trọng 4,69\% GDP tỉnh.

Bảng 1. Tổng hợp các chỉ tiêu phát triển của ngành du lịch giai đoạn 2015-2019 [20].

\begin{tabular}{cccccccc}
\hline STT & Chỉ tiêu & ĐVT & $\mathbf{2 0 1 5}$ & $\mathbf{2 0 1 6}$ & $\mathbf{2 0 1 7}$ & $\mathbf{2 0 1 8}$ & $\mathbf{2 0 1 9}$ \\
\hline \multirow{2}{*}{ I } & $\begin{array}{c}\text { Doanh thu các cơ } \\
\text { sở lưu trú }\end{array}$ & $\begin{array}{c}\text { Triệu } \\
\text { đồng }\end{array}$ & 965 & 1.212 & 1.500 & 1.807 & 1.897 \\
1 & Nhà nước & $\begin{array}{c}\text { Triệu } \\
\text { đồng }\end{array}$ & 111 & 127 & 157 & - & - \\
2 & Ngoài nhà nước & $\begin{array}{l}\text { Triệu } \\
\text { đồng }\end{array}$ & 854 & 1.085 & 1.343 & 1.807 & 1.897 \\
& & $\begin{array}{l}\text { Triệu } \\
\text { đồng }\end{array}$ & 606 & 748 & 793 & 959 & 1.007 \\
\hline
\end{tabular}




\begin{tabular}{|c|c|c|c|c|c|c|c|}
\hline STT & Chỉ tiêu & ĐVT & 2015 & 2016 & 2017 & 2018 & 2019 \\
\hline- & Cá thể & $\begin{array}{l}\text { Triệu } \\
\text { đồng }\end{array}$ & 359 & 464 & 707 & 848 & 890 \\
\hline II & $\begin{array}{c}\text { Số lượt khách du } \\
\text { lịch }\end{array}$ & Lượt & 100.375 & 133.220 & 166.718 & 380.645 & 399.705 \\
\hline 1 & Khách trong nước & Lượt & 88.282 & 117.930 & 150.487 & 173.520 & 183.135 \\
\hline 2 & Khách quốc tế & Lượt & 12.093 & 15.290 & 16.231 & 16.250 & 17.320 \\
\hline 3 & $\begin{array}{l}\text { Số ngày khách luu trú } \\
\text { phục vụ }\end{array}$ & Lượt & 110.985 & 134.119 & 165.535 & 190.875 & 199.250 \\
\hline
\end{tabular}

\subsubsection{Sức ép về dân số và vấn đề di cư}

Trong những năm gần đây, quá trình công nghiệp hóa hiện đại hóa trên địa bàn tỉnh diễn ra khá nhanh, kết hợp với quá trình đầu tư xây dựng và phát triển các $\mathrm{KCN} / \mathrm{CCN}$ đã thu hút dân cư lao động ở các nơi khác hoặc dân cư ở vùng nông thôn di chuyển đến thể hiện ở gia tăng dân số đô thị từ 234.679 người năm 2015 lên 241.796 người năm 2019 (chiếm 27,3\% dân số toàn tỉnh), trong đó thành phố Bạc Liêu tập trung dân cư đông nhất (chiếm 17,41\% dân số toàn tỉnh) và có mật độ dân số 881 người $/ \mathrm{km}^{2}$. Quá trình di dân gây ra sự phân cực về dân số giữa nông thôn và đô thị. Dự báo đến năm 2020, dân số tỉnh Bạc liêu vào khoảng 953.285 người (tăng bình quân $1 \%$ /năm), đến năm 2025 vào khoảng 988.069 người (tăng bình quân $0,9 \% /$ năm). Vấn đề gia tăng dân số và di cư đã gây những ảnh hưởng nhất định đến chất lượng môi trường của tỉnh như sau: (1) Sự phát triển không đồng bộ giữa hạ tầng kỹ thuật bảo vệ môi trường và quá trình gia tăng dân số đã gây ảnh hưởng chất lượng một số kênh rạch tại các đô thị tập trung; (2) Gia tăng dân số kéo theo gia tăng lượng chất thải làm giảm diện tích đất cho phát triển nông nghiệp, đất rừng, cây xanh,.. làm thay đồi điều kiện khí hậu khu vực; (3) Nhu cầu về nguồn tài nguyên cũng gia tăng, đặt biệt là đối với tài nguyên nước mặt tạo ra những áp lực đối với nguồn tài nguyên này.

\subsubsection{Tác động của phát triển công nghiệp đối với môi trường nước mặt}

Sự hình thành và phát triển của các $\mathrm{KCN} / \mathrm{CCN}$ tập trung, các cơ sở sản xuất TTCN trước hết làm gia tăng áp lực đối với tài nguyên nước trong việc cung cấp lượng nước phục vụ sản xuất. Bên cạnh đó, nước thải, khí thải, $\mathrm{CTR}$ và $\mathrm{CTNH}$ phát sinh từ quá trình sản xuất nếu không được xử lý triệt để sẽ gây tác động đến môi trường tiếp nhận như không khí, nước mặt, đất. Các cơ sở sản xuất công nghiệp tỉnh Bạc Liêu chủ yếu tập trung ở khu vực phía Nam QL1A, dọc theo kênh Bạc Liêu-Cà Màu cùng với việc tập trung dân số đang gây áp lực lớn đến môi trường nước kênh Bạc Liêu-Bạc Liêu và vùng Nam QL1A. Các kết quả quan trắc giai đoạn 2016-2019 cho thấy chất lượng môi trường tại các khu vực tập trung đông dân cư như TP.Bạc Liêu, thị trấn Hòa Bình, thị xã Giá Rai, thị trấn Hộ Phòng đang bị ô nhiễm ở một số thông số. Phát triển công nghiệp, đặc biệt là công nghiệp chế biến thực phẩm, thủy sản thường đi kèm với việc phát triển các vùng nguyên liệu, đặc biệt là nuôi tôm cá. Từ đó làm gia tăng tổng lưu lượng nước thải từ hoạt động NTTS với nồng độ các chất dinh dưỡng, thuốc kháng sinh và vi khuẩn gây bệnh cao gây ô nhiễm nguốn nước.

\subsubsection{Tác động của phát triển nông nghiệp tới môi trường}

Trong sản xuất nông nghiệp, do lạm dụng các loại thuốc bảo vệ thực vật cũng như phân bón hóa học mà trung bình $20-30 \%$ lượng thuốc và phân bón không được cây trồng hấp thụ sẽ theo nước mưa và nước tưới chảy vào nguồn nước mặt, tích lũy gây ô nhiễm nguồn nước mặt. Các loại CTNH như vỏ bao bì chứa các loại hóa chất BVTV, trừ cỏ,... đều bị nông dân 
vứt bỏ ngay tại đồng ruộng, vườn cây là nguồn gây tác động tiềm tàng cho môi trường nước. Các hoạt động chăn nuôi trên địa bàn tỉnh Bạc Liêu (Chủ yếu là gia súc, gia cầm) chủ yếu theo hình thức gia trại, hộ gia đình, hầu hết chất thải (nước thải, CTR) đều chưa được xử lý, thải thẳng ra môi trường nước gây ô nhiễm cục bộ nguồn nước. Lượng chất thải chăn nuôi có chứa nhiều vi khuẩn, ký sinh gây bệnh khi đi vào nguồn nước sẽ gây ra nguy cơ lan tràn dịch bệnh. Hoạt động NTTS nước lợ phát thải một lượng lớn nhất chất thải gây ảnh hưởng rất lớn đến chất lượng môi trường nước. Nuôi tôm công nghiệp, bán công nghiệp phát thải khoảng $13.500 \mathrm{~m}^{3}$ nước thải/ha/vụ. Đây là nguồn ô nhiễm lớn nhất trên địa bàn tỉnh Bạc Liêu. Nước thải sau vụ nuôi chứa nhiều vi sinh vật gây bệnh như Vibrio, aeromonas, Ecoli,.. cùng nhiều loại nấm và nguyên sinh động vật không được xử lý triệt để thải thẳng ra nguồn nước tiếp nhận gây ô nhiễm nguồn nước, lan tràn dịch bệnh và thất mùa.

\subsubsection{Tác động của phát triển du lịch tới môi trường}

Số lượng khách du lịch đến tỉnh Bạc Liêu ngày càng gia tăng có tác dụng thúc đẩy phát triển của các ngành thương mại, dịch vụ: như vận tải hành khách và hàng hóa, dịch vụ lưu trú, mua bán hàng hóa, ăn uống,...làm ảnh hưởng không nhỏ đến môi trường nước mặt của tỉnh. Thông thường, lượng chất thải sinh hoạt như nước thải, CTR sinh hoạt khách du lịch gấp 2-2,5 người dân sinh sống tại địa bàn. Do đó, phát triển du lịch thường đi đôi với gia tăng lượng chất thải gây nhiều áp lực lên tài nguyên nước mặt.

\subsection{Kết quả phân vùng chất lương nước mặt theo các vùng phát triển kinh tế}

Nghiên cứu đã đánh giá chất lượng nước theo các chỉ tiêu hóa lý, tính toán chỉ số chất lượng nước WQI mặt tỉnh Bạc Liêu. Các điểm quan trắc các chỉ tiêu (TSS, BOD ${ }_{5}, \mathrm{COD}$, $\mathrm{N}-\mathrm{NH}_{4}, \mathrm{~N}-\mathrm{NO}_{2}, \mathrm{P}-\mathrm{PO}_{4}$, Coliform...), cho từng vùng phát triển nông nghiệp, nuôi trồng thủy sản cho thấy đều vượt quy chuẩn cho phép QCVN 08-MT: 2015/BTNMT [21-22] từ 0-10 lần. Kết quả tính toán chỉ số chất lượng nước WQI cho các tiểu vùng đa số nằm trong khoảng 51-62 (Bảng 2) (mức độ ô nhiễm thấp) tại các điểm quan trắc nguồn nước tại các khu vực này chủ yếu sử dụng cho mục đích tưới tiêu và các mục đích tương đương khác (Hình 4 , Hình 5 ).

Bảng 2. Chỉ số WQI chất lượng nước mặt tỉnh Bạc Liêu mùa khô 2014-2019.

\begin{tabular}{|c|c|c|c|c|}
\hline STT & Vị trí lấy mẫu & WQI & Màu & Mục Đích Sử Dụng \\
\hline \multirow{3}{*}{1} & Cửa Nhà Mát, TP. & & & Sử dụng cho mục đích tưới \\
\hline & Bạc Liêu & 54 & Vàng & và các mục đích tương đương \\
\hline & Cống Hưng Thành, & & & Sử dụng cho mục đích tưới \\
\hline \multirow[t]{2}{*}{2} & Huyện Vĩnh Lợi & 55 & Vàng & và các mục đích tương đương \\
\hline & Cống Cái Cùng, & & & Sử dụng cho mục đích tưới \\
\hline \multirow[t]{2}{*}{3} & Huyện Hòa Bình & 51 & Vàng & và các mục đích tương đương \\
\hline & Cống Đầu Bằng, Thị xã & & & Sử dụng cho mục đích tưới \\
\hline \multirow[t]{2}{*}{4} & Giá Rai & 56 & Vàng & và các mục đích tương đương \\
\hline & Ngã tư Chủ Chí, huyện & & & Sử dụng cho mục đích tưới \\
\hline \multirow[t]{2}{*}{5} & Phước Long & 53 & Vàng & và các mục đích tương đương \\
\hline & Cửa Gành Hào, & & & Sử dụng cho mục đích tưới \\
\hline 6 & Huyện Đông Hải & 59 & Vàng & và các mục đích tương đương \\
\hline & Ngã Tư Ninh Quới, & & & Sử dụng cho mục đích tưới \\
\hline 7 & Huyện Hồng Dân & 61 & Vàng & và các mục đích tương đương \\
\hline & Vĩnh Lộc - Ba Đình, & & & Sử dụng cho mục đích tưới \\
\hline 8 & Huyện Hồng Dân & 62 & Vàng & và các mục đích tương đương \\
\hline
\end{tabular}


Bạc Liêu có hai mùa mưa và mùa khô rõ rệt, mùa khô trên vùng đất Bạc Liêu từ tháng 12 đến tháng 4 năm sau, với 5 tháng có giờ nắng nhiều, lưu lượng nước mặt trên các sông, kênh rạch ở Bạc Liêu giảm đi rất nhiều, bên cạnh đó hoạt động xả thải chất ô nhiễm vẫn cứ diễn ra hằng ngày, hằng giờ. Chính vì điều đó nhiều con sông, kênh rạch ở Bạc Liêu ô nhiễm nặng vào mùa khô (Bảng 2).

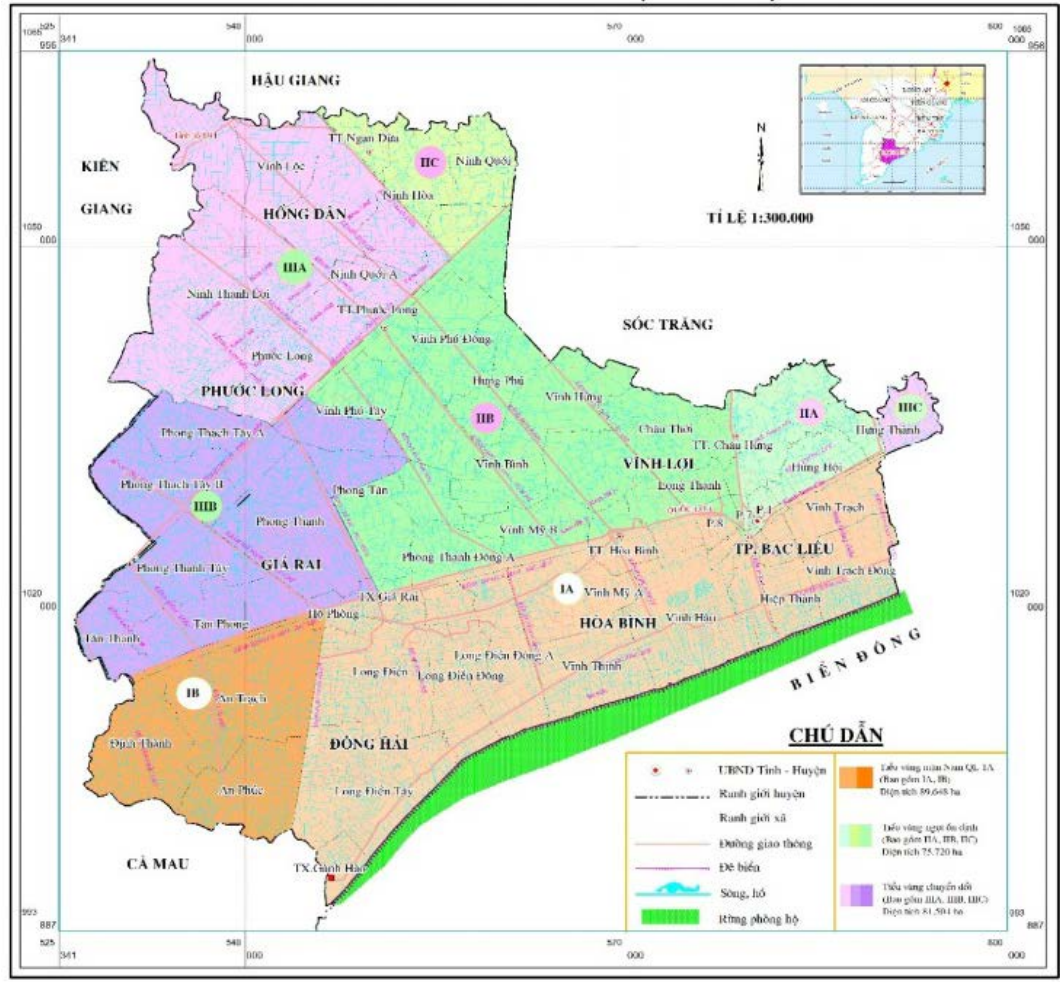

Hình 4. Bản đồ các vùng sản xuất nông nghiệp.

BẢN Đố CHẤT LỰ̛̛̛̂G NỨ̛̛C TỈNH BAC LIÊU - MỪA KHÔ

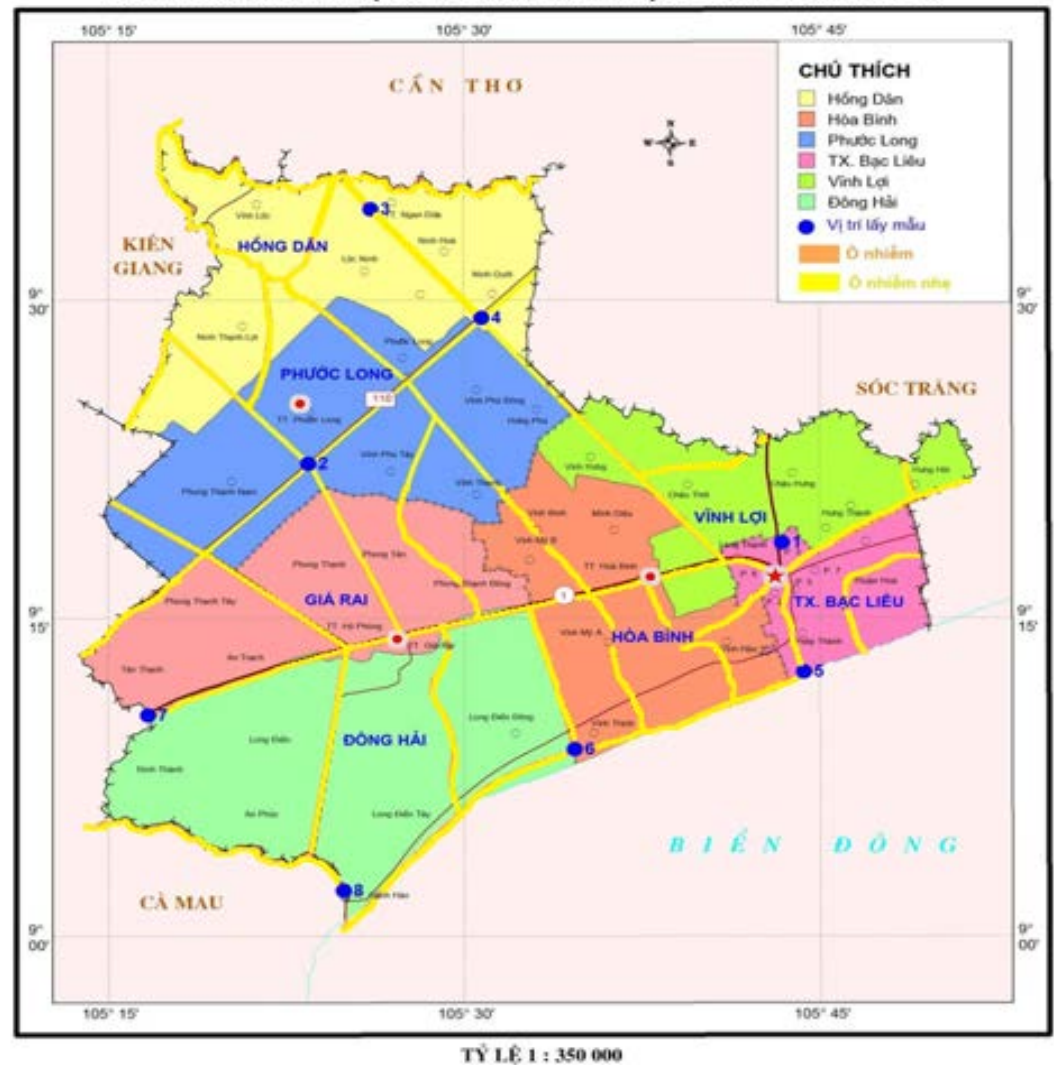

Hình 5. Phân vùng chất lượng nước mùa khô tỉnh Bạc Liêu. 
Tiêu chí phân vùng là Chỉ số WQI chất lượng nước mặt tỉnh Bạc Liêu mùa khô giai đoan 2014-2019, chất lượng nước mặt các sông, kênh rạch chính ở Bạc Liêu nằm mức cuối theo Quyết định 1460/QĐ-TCMT về chất lượng nước (màu vàng) (Bảng 3). Vào mùa khô chất lượng nước ô nhiễm đa phần trong mức chất lượng nước sử dụng cho mục đích tưới tiêu và các mục đích tương đương khác. Do hoạt động xả thải lớn trong khi lưu lượng nước thấp nên chất lượng nước mặt ở trên địa bàn tỉnh cũng có rất nhiều sông, kênh rạch đang bị ô nhiễm.

Bảng 3. Chỉ số WQI chất lượng nước mặt tỉnh Bạc Liêu mùa mưa 2014-2019.

\begin{tabular}{|c|c|c|c|c|}
\hline STT & Vị trí lấy mẫu & WQI & Màu & Mục Đích Sử Dụng \\
\hline \multirow{2}{*}{1} & Cửa Nhà Mát, TP. & & & Sử dụng cho mục đích tưới \\
\hline & Bạc Liêu & 51 & Vàng & và các mục đích tương đương \\
\hline 2 & $\begin{array}{l}\text { Cống Hưng Thành, } \\
\text { Huyện Vĩnh Lợi }\end{array}$ & 56 & Vàng & $\begin{array}{l}\text { Sử dụng cho mục đích tưới } \\
\text { và các mục đích tương đương }\end{array}$ \\
\hline 3 & $\begin{array}{l}\text { Cống Cái Cùng, } \\
\text { Huyện Hòa Bình }\end{array}$ & 51 & Vàng & $\begin{array}{l}\text { Sử dụng cho mục đích tưới } \\
\text { và các mục đích tương đương }\end{array}$ \\
\hline 4 & $\begin{array}{l}\text { Cống Đầu Bằng, Thị } \\
\text { xã Giá Rai }\end{array}$ & 53 & Vàng & $\begin{array}{l}\text { Sử dụng cho mục đích tưới } \\
\text { và các mục đích tương đương }\end{array}$ \\
\hline 5 & $\begin{array}{l}\text { Ngã tư Chủ Chí, huyện } \\
\text { Phước Long }\end{array}$ & 52 & Vàng & $\begin{array}{l}\text { Sử dụng cho mục đích tưới } \\
\text { và các mục đích tương đương }\end{array}$ \\
\hline 6 & $\begin{array}{l}\text { Cửa Gành Hào, } \\
\text { Huyện Đông Hải }\end{array}$ & 52 & Vàng & $\begin{array}{l}\text { Sử dụng cho mục đích tưới } \\
\text { và các mục đích tương đương }\end{array}$ \\
\hline 7 & $\begin{array}{l}\text { Ngã Tư Ninh Quới, } \\
\text { Huyện Hồng Dân }\end{array}$ & 61 & Vàng & $\begin{array}{l}\text { Sử dụng cho mục đích tưới } \\
\text { và các mục đích tương đương }\end{array}$ \\
\hline 8 & $\begin{array}{l}\text { Vĩnh Lọc-Ba Đình, Huyện } \\
\text { Hồng Dân }\end{array}$ & 60 & Vàng & $\begin{array}{l}\text { Sử dụng cho mục đích tưới } \\
\text { tiêu và các mục đích tương }\end{array}$ \\
\hline
\end{tabular}

Tiêu chí phân vùng là Chỉ số WQI, chất lượng nước mặt tỉnh Bạc Liêu mùa mưa 2014-2019, có cải thiện nhưng có nhiều khu vực lại ô nhiễm so với mùa khô. Mùa mưa, CLN chủ yếu tình trạng (màu vàng), nước chỉ sử dụng được cho tưới tiêu, không có khu vực có chất lượng nước khá sạch và sạch cho hoạt động cung cấp nước cho sinh hoạt. Môi trường nước mặt của tỉnh Bạc Liêu 2014-2019 đã có dấu hiệu ô nhiễm hữu cơ nhẹ biểu hiện BOD5, COD, TSS và Coliform đều vượt quy chuẩn cho phép vài lần. Trên các trục sông chính và các kênh rạch chỉ tiêu $\mathrm{COD}$ và $\mathrm{BOD}_{5}$ vượt tiêu chuẩn từ $1,0-3,0$ lần. Ô nhiễm nước do nước thải sinh hoạt, chế biến thủy sản và các sản phẩm từ nông nghiệp, các làng nghề là những loại nước thải có nồng độ các chất hữu cơ cao.

Kết hợp chất lượng nước đã được nghiên cứu với chế độ ngập, thời gian ngập và quy hoạch các vùng sản xuât trên địa bàn tỉnh, có được kết quả phân vùng:

Vùng phát triển kinh tế hiệu quả vùng sinh thái phía Bắc Quốc lộ $1 \mathrm{~A}$, có diện tích tự nhiên 157.224 ha và được chia thành 02 Tiểu vùng: (1) Tiểu vùng giữ ngọt ổn định (sinh thái ngọt), có diện tích tự nhiên 75.720 ha, các yếu tố khí tượng, thủy văn, đất đai, nguồn nước tương đối thuận lợi cho phát triển sản xuất nông nghiệp và thủy sản; (2) Tiểu vùng chuyển đổi sản xuất sinh thái mặn lợ đan xen, trong đó đất chuyên nuôi trồng thủy sản 35.609 ha, đất tôm-lúa 23.134 ha, đất SXNN 12.274 ha.

Quá trình phát triển các hình thức sản xuất trên địa bàn tỉnh có thể được chia tách thành 3 vùng rõ rệt: vùng sinh thái nước mặn, vùng sinh thái nước ngọt và vùng sinh thái ảnh hưởng lợ. Vùng sinh thái phía Nam Quốc lộ $1 \mathrm{~A}$ (sinh thái mặn), diện tích 89.648,12 ha, vùng đất ven biển $10.221,96$ ha có khả năng phát triển nông nghiệp toàn diện, lĩnh vực nuôi trồng thủy sản 
theo hướng thâm canh và làm muối. Vùng đặc quyền kinh tế biển rộng $20.742 \mathrm{~km}^{2}$ có trữ lượng tôm, cua, cá khá dồi dào, khai thác thủy sản quanh năm. Nhiều cửa biển lớn như Gành Hào, Cái Cùng và Nhà Mát phát triển mạnh vận tải và du lịch, mở rộng hợp tác quốc tế và an ninh quốc phòng.

\section{Kết luận}

Chất lượng nước mặt trên địa bàn tỉnh Bạc Liêu giai đoạn 2014-2019 có diễn biến phức tạp, xu hướng tăng dần tỉ lệ nước mặt bị ô nhiễm theo các vùng kinh tế. Tỉ lệ nước mặt vùng canh tác và phát triển các ngành kinh tế bị ô nhiễm nặng tăng từ $20 \%$ lên $50 \%$; Số lượng các điểm ô nhiễm tăng theo hàng năm, tỷ lệ nước phục vụ giao thông giảm từ $10 \%$ xuống còn $2 \%$, nước phục vụ cho sinh hoạt giảm từ $50 \%$ xuống $10 \%$ tổng lượng nước toàn tỉnh.

Từ kết quả đánh giá chất lượng, cùng với quy hoạch phát triển kinh tế trên toàn tỉnh, trên cơ sở phát triển các vùng kinh tế với các tiêu chí cho từng vùng. Kết quả phân vùng chất lượng nước theo phát triển kinh tế, làm cơ sở cho việc đề xuất các giải pháp khoa học phát triển bền vững nông nghiệp, ngư nghiệp phù hợp với đặc trưng của từng vùng trên địa bàn tỉnh Bạc Liêu.

Lò̀i cảm ơn: Bài báo được hoàn thành từ kết quả thực hiện đề tài "Nghiên cứu phân vùng chất lượng nước mặt theo diễn biến phát triển các vùng kinh tế của tỉnh Bạc Liêu". Viện Phát triển Công nghệ Môi trường và Tài nguyên nước Phú Mỹ, 2019.

Lời cam đoan: Tác giả cam đoan bài báo này là công trình nghiên cứu mà tác giả làm Chủ nhiệm đề tài, chưa công bố ở đâu, không sao chép; không có sự tranh chấp lợi ích trong nhóm tác giả.

\section{Tài liệu tham khảo}

1. Al-Ani, M.Y.; Al-Nakib, S.M.; Ritha, N.M.; Nouri, A.H. Water quality index applied to the classification and zoning of Al-Jaysh canal, Baghdad - Iraq. $J$. Environ. Sci. Health., Part A 1987, 22, 305-319. doi:10.1080/10934528709375351.

2. Sullivan, D.J. Surface Water Quality Assessment of the Upper Illinois River Basin in Illinois, Indiana, and Wisconsin, U.S. Department of the Interior and U.S. Geological Survey, 1990.

3. Shams, G.K.; Yusefzadeh, A.; Godini, H. Water Quality Zoning Based on Water Quality Index and Wilcox Index Using Geographic Information System, 2014.

4. Huynh, P. Method of calculation \& application of WQI index to assess the status water quality and proposal of management Luy river Binh thuan province. VN J. Hdrometeorol. 2019, 2, 9-15.

5. Huynh, P. Irrigation construction solution for rising Litopenaeus Vannamei in Mekong delta. The international conference on science, technology and society studies (STS) (HUTECH), 2020. ISBN 978-604-67-1574-0.

6. Wang, Y.; Wang, P.; Bai, Y.; Tian, Z.; Li, J.; Shao, X.; Mustavich, L.F.; Li, B.L. Assessment of surface water quality via multivariate statistical techniques. A case study of the Songhua River Harbin region, China. J. Hydro-environ. Res. 2011, 7, 30-40.

7. Nguyên, N.X.; Hạ, T.Đ. Chất lượng nước sông hồ và Bảo vệ môi trường nước, NXB Khoa học và Kỹ thuật Hà Nội, 2004.

8. Bhargava, D.S. Use of water quality index for river classification and zoning of Ganga river. Environ. Pollut. Series B, Chem. Phys. 1983, 6, 51-67.

9. Karamouz, M.; Mahjouri, N.; Kerachian, R. River Water Quality Zoning: A Case Study of Karoon and Dez River System. J. Environ. Health Sci. Eng. 2005, 1, 16-27.

10. Liu, X.; Zhou, S.; Qi, S.; Yang, B. Chen, Y.; Huang, R.; Du, P. Zoning of rural water conservation in China: A case study at Ashihe River Basin. Int. Soil Water Conserv. Res. 2015, 3, 130-140. 
11. Trình, L. Nghiên cứu phân vùng chất lượng nước theo các chỉ số chất lượng nước (WQI) và đánh giá khả năng sử dụng các nguồn nước sông kênh rạch ở vùng TP.HCM. Tp. Hồ Chí Minh, 2008.

12. Chính, P.V. Nghiên cứu mô hình tính toán đánh giá chất lượng nước sông Đồng Nai đến năm 2020. Nghiên cứu khoa học, 2011.

13. Nguyên, N.T.T. Nghiên cứu phân vùng chất lượng nước Vịnh Hạ Long, tỉnh Quảng Ninh và đề xuất giải pháp quản lý và sử dụng, 2014.

14. Sở Tài nguyên và Môi trường tỉnh Bạc Liêu (2015-2020). Báo cáo hiện trạng môi trường tỉnh Bạc Liêu giai đoạn 2015-2020.

15. Đàn, N.V. Úng dụng chỉ số chất lượng nước (WQI) và hệ thống thông tin địa lý (GIS) để phân vùng chất lượng nước nuôi tôm ở đầm phá xã phú thuận, huyện phú vang, tỉnh thừa thiên huế, Đại Học Huế, 2014.

16. Hợp, N.V.; Thi, P.N.A.; Hưng, N.M.; Tờ, N.C.; Cường, N.M. Đánh giá chất lượng nước sông Bồ ở tỉnh Thừa Thiên Huế dựa vào chỉ số chất lượng nước (WQI). Tạp chí khoa hoc, Đại hoc Hué 2010, 58, 77-85.

17. Lan, T.T.; Long, N.P. Đánh giá chất lượng nước mặt bởi chỉ số chất lượng nước (WQI) tại rạch Cái Sao, tỉnh An Giang, Việt Nam. Trung tâm Quan trắc và Công nghệ Tài nguyên- Môi trường, An Giang, Việt Nam, 2011.

18. Cục thống kê tỉnh An giang. Niên giám tống kê tỉnh năm 2018, 2019.

19. Anh, T.N.T. Nghiên cứu phân vùng chất lượng nước sông Hương theo chỉ số chất lượng nước (WQI) góp phần bảo vệ và khai thác nguồn nước, 2009.

20. Cục thống kê tỉnh Bạc Liêu. Niên giám thống kê tỉnh năm 2017, 2018, 2019.

21. Bộ Tài nguyên và Môi trường. Quy chuẩn kỹ thuật quốc gia về CLN mặt, 2015.

22. Bộ Tài nguyên và Môi trường. Tổng cục Môi trường. QĐ số 879/QĐ-TCMT, 2011.

\title{
Study on zoning of surface water quality according to developments in economic regions of Bac Lieu province
}

\section{Phu Huynh ${ }^{1^{*}}$ \\ ${ }^{1}$ Ho Chi Minh City University of Technology (HUTECH); h.phu@hutech.edu.vn}

\begin{abstract}
The paper presents research on zoning of surface water quality according to developments in economic regions of Bac Lieu province. Effective economic development with water source as an essential means of production, water quality determines success or failure, need to analyze the characteristics of water in the regions as a combination of factors with spatial distribution, inundation regime, water quality for the planning of agriculture, forestry, fisheries, tourism, etc. Research using methods, surveying, water sampling, analyzing indicators physical digestion (TSS, BOD $, \mathrm{COD}, \mathrm{N}-\mathrm{NH}_{4}, \mathrm{~N}-\mathrm{NO}_{2}, \mathrm{P}-\mathrm{PO}_{4}$, Coliform...), calculate WQI index; Comparison with QCVN 08-MT:2015/BTNMT. The results have zoned water quality: (i) Economic development area in the north of National Highway 1A, with a natural area of 157,224 ha; (a) The sub-region for stable freshness (fresh ecology), with a natural area of 75,720 ha, with meteorological factors, hydrology, soil, and water resources is relatively favorable for the development of agricultural and aquatic production real; (b) The sub-region of mixed brackish ecological production, of which land for aquaculture is 35,609 ha, rice-shrimp land 23,134 ha, agricultural production land 12,274 ha; (ii) The region strongly develops sea transport and tourism, expanding international cooperation and protecting security and defense.
\end{abstract}

Keywords: Bac Lieu; Brackish ecology; Ecological sub-region; Economic stratification; Surface water. 